\title{
Respon Fisiologi Domba pada Sistem Pemeliharaan dan Pemberian Jenis Konsentrat Berbeda
}

\author{
Physiological Response on Local Sheep in Rearing Systems and Different Concentrate
}

\author{
A. C. Gonzaga dos Santos 1 , M. Yamin ${ }_{2}^{2}$ R. Priyanto ${ }^{2}, \&$ H. Maheshwari ${ }^{3}$ \\ ${ }^{1}$ Ilmu Produksi dan Teknologi Peternakan, Fakultas Peternakan, IPB \\ ${ }^{2}$ Departmen Ilmu Produksi dan Teknologi Peternakan, Fakultas Peternakan, IPB \\ ${ }^{3}$ Departemen Fisiologi dan Farmakologi, Fakultas Kedokteran Hewan, IPB, \\ Jl. Agatis Kampus IPB Dramaga, Bogor 16680 \\ Email koresponden author: rhanulolin18@gmail.com (081237921107)
}

\begin{abstract}
Sheep is one of the livestock commodities that is developed and utilized by farmer to meet the increasing demand of animal protein. This study aimed to investigate physiological responses of local sheep that were kept on different raising system and given different type concentrate. The study used 24 heads of local sheep with an average initial live weight of $19.79 \pm 2.47 \mathrm{~kg}$. The experiment was set up in a completely randomized design with two factors. The first factor was rearing system (intensive and semi intensive) and second factor was type of concentrate feed (green and comercial concentrates). The parameters observed were heart rate, rectal temperature, respiration rate, differential leukocytes $\mathrm{N} / \mathrm{L}$ and cortisol hormone levels. The data were analyzed by repeated mensure analysis of variance (repeted ANOVA). The results showed that the type of concentrate did not affect blood profile and cortisol hormone levels. Sheep's physiological response (respiration rate, heart rate and rectal temperature) were significantly $(\mathrm{P0}<0.5)$ influenced by rearing system.
\end{abstract}

Keywords: blood profile, cortisol level, local sheep, physiological response

\section{PENDAHULUAN}

Domba merupakan salah satu komoditas ternak yang dikembangkan dan dimanfaatkan oleh masyarakat Indonesia pada umumnya dalam pemenuhan kebutuhan protein hewani. Berdasarkan data Badan Pusat Statistik (BPS) 2017 melaporkan bahwa populasi ternak domba meningkat setiap tahun hingga mencapai 16.462 juta ekor pada tahun 2017. Populasi domba berkembang setiap tahun namun masih ada beberapa faktor yang menjadi penyebab rendahnya komsumsi daging domba hanya $2 \%$ (Statistik PKH, 2017). Rosyidi (2006) menyatakan bahwa daging domba di Indonesia masih kurang diminati oleh masyarakat akibat adanya isu-isu negatif bahwa daging domba memiliki kandungan lemak dan kolesterol yang tinggi serta memiliki bau khas yang tajam.

Presepsi negatif terhadap kolesterol, sehinga saat ini sedang diupayakan menghasilkan daging domba yang rendah kolesterolnya melalui pemberian konsentrat hijau (Indigofera zollingeriana) dengan pemeliharaan secara semi intensif. Peningkatan populasi ternak domba setiap tahun seiring dengan meningkatnya permintaan terhadap daging domba, untuk itu perlu ada strategi dalam upaya meningkatkan produktivitas domba melalui perbaikan manajemen pemeliharaan.
Sistem pemeliharaan yang diterapkan di Indonesia pada umumnya masih bersifat tradisional sehingga menjadi kendala terhadap produktivitas domba. Manajamen pemeliharaan yang sesuai diharapkan dapat meningkatkan produktivitas ternak domba, salah satunya dengan penambahan konsentrat hijauan (Indigofera zollingeriana) yang diketahui memiliki kandungan protein yang tinggi. Hasil penelitian Sirait dan Simanihuruk (2010) memperoleh kandungan protein kasar pada Indigofera Sp 24,17 (\%). Menurut Wilson dan Rowe (2008) menyatakan bahwa Indigofera $\mathrm{Sp}$. adalah sejenis leguminosa pohon yang memiliki produksi biomasa serta kandungan nutrisi yang tinggi pada kondisi yang normal dan sub optimal. Indigofera ini telah dikembangkan oleh Fakultas Peternakan IPB yang dimanfaatkan peternak sebagai sumber pakan bekualitas dan dapat terjangkau oleh peternak karena harga relatif rendah dari konsentrat konvensional yang bahan bakunya serealia. Konsep pemberian indigofera ini juga dapat mengembalikan domba sebagai herbivora untuk mengkonsumsi hijauan. Selain itu, faktor yang perlu diperhatikan adalah kondisi nyaman (comfort zone) pada ternak domba dengan batas maksimum dan minimum yang dapat diterima oleh ternak domba.

Lingkungan akan memberikan tantangan tersendiri bagi ternak yang dipelihara pada daerah tropis dikarenakan 
memperoleh tambahan panas (heat load) dari lingkungan eksternal, terutama pada siang hari dikarenakan suhu lingkungan yang lebih tinggi (Altan et al. 2000). Kondisi temperature lingkungan yang tinggi akan mempengaruhi respon fisiologis dan profil darah domba. Kondisi demikian jika terus menerus akan menyebabkan ternak domba mengalami cekaman atau stres yang akan berakibat pada penurunan produktivitas. Yani et al. (2013) menyatakan bahwa cekaman panas pada ternak akan berakibat pada konversi pakan yang dikonsumsi sapi digunakan untuk mereduksi stres sehingga tujuan utama pemberian pakan untuk meningkatkan bobot badan akan mengalami gangguan karena sebagian pakan yang dikonsumsi digunakan untuk mereduksi panas. Nurmi (2016) menyatakan bahwa peningkatan suhu dan kelembapan dapat mempengaruhi respon fisiologis ternak melalui perubahan suhu tubuh, kecepatan denyut jantung, dan peningkatan laju respirasi. Atrian dan Shahryar (2012) menyatakan bahwa temperatur lingkungan yang tinggi menyebabkan perubahan sistem hormonal, enzimatik dan metabolik yang dapat menyebabkan ternak mengalami stres.

Sistem pemeliharaan intensif dan semi intensif dengan pemberian jenis konsentrat yang berbeda pada penelitian ini merupakan fokus utama untuk melihat yang paling berpengaruh terhadap produksi domba sesuai dengan aspek kesejahteraan ternak. Masih terbatasnya informasi tentang sistem pemeliharaan dengan pemberian konsentrat hijau (Indigofera zollingeriana) yang diduga dapat meningkatkan produktivitas pada ternak domba, maka perlu dikaji lebih jauh dari berbagai aspek pemeliharaan. Salah satunya dengan melihat respon fisiologis, status diferensial leukosit dan kadar hormon kortisol sebagai penentu apakah domba yang dipelihara pada sistem pemeliharaan intensif maupun semi intensif berada dalam zona yang nyaman. Berdasarkan dengan fakta-fakta di atas maka perlu dilakukan penelitian mengenai respon fisiologis domba pada sistem pemeliharaan dan pemberian jenis konsentrat berbeda. Penelitian ini bertujuan untuk mengetahui pengaruh pemberian jenis konsentrat yang berbeda terhadap respon fisiologi domba dengan sistem pemeliharaan yang berbeda.

\section{MATERI DAN METODE}

\section{Waktu dan Lokasi Penelitian}

Penelitian ini telah dilaksanakan dari bulan September 2017 hingga Maret 2018 yang berlokasi di Unit Pendidikan dan Penelitian Peternakan Jonggol (UP3J) Fakultas Peternakan, Institut Pertanian Bogor, Jawa Barat. Pengamatan diferensial leukosit dan hormon kortisol diamati di Laboratorium Fisiologi dan Farmakologi Fakultas Kedokteran Hewan, Institut Pertanian Bogor.

\section{Bahan}

Bahan yang digunakan dalam penelitian ini yaitu 24 ekor domba lokal dengan kisaran bobot badan awal $19,79 \pm 2,47 \mathrm{KG}$. Dua belas ekor domba dipelihara secara semi intensif (digembalakan pukul 10:00-17:00 WIB) dan dua belas ekor dipelihara secara intensif. Masing-masing manajemen pemeliharaan diberikan konsentrat komersil dan konsentrat hijau, hijauan berupa rumput Brachiaria humidicola dan air disediakan adlibitum, pemberian konsentrat dilakukan pukul 07.00 WIB.

\section{Alat}

Peralatan yang digunakan dalam penelitian ini antara lain thermohigrometer, cooling box, DRG Cortisol Enzyme Immunoassay Kit (Cortisol ELISA, EIA-1887), tabung ethylene diamaine tetracetic (EDTA), multi drawing needle (18-21G), needle holder, vucum tube, rak pipet, tabung eppendorf, sentrifus refigerator, tabung vacumtainer, hematology analizer, freezer, mikropipet, ELISA reader, kertas penyerap, object glass, slide box, alkohol $70 \%$, metanol, termometer, higrometer dan stetoskop erkaphon adult.

\section{Prosedur Penelitian}

Pengumpulan data menggunakan metode observasi di lapangan dan analisis laboratorium. Observasi dilakukan melalui pengamatan secara langsung di lokasi penelitian yang meliputi suhu lingkungan dan respon fisiologis. Pengamatan difrensial leukosit dan kadar hormon kortisol diamati di laboratorium fisiologi dan farmakologi Fakultas Kedokteran Hewan, IPB.

\section{Peubah yang diamati \\ Suhu $\left({ }^{\circ} \mathrm{C}\right)$ dan kelembapan udara}

Pengamatan suhu dan kelembapan udara diukur dengan mengunakan alat thermohigrometer. Pengukuran suhu dan kelembapan udara diawali dengan penentuan titik pengamatan, yaitu dalam kandang dan di luar kandang (tempat penggembalaan). Data diukur tiga kali sehari yaitu pagi hari 06.00-07.00 WIB, siang hari 12.00-13.00 WIB dan sore hari 17.00-18.00 WIB.

\section{Respon Fisiologi domba}

Pengamatan respon fisiologi pada penelitian ini meliputi: frekuensi denyut jantung, frekuensi repirasi dan suhu rektal. Pengukuran frekuensi denyut jantung diamati dengan menggunakan stetoskop yang ditempelkan pada bagian dada sebelah kiri selama satu menit. Pengukuran frekuensi respirasi diamati dengan cara menghitung frekuensi gerakan tulang rusuk, perut, dan rongga dada, selanjutnya menghitung banyaknya respirasi dalam satu menit. Suhu rektal diamati dengan cara memasukkan thermometer digital klinis sampai menempel ke dinding rektum pembacaan dilakukan setelah suara alarm thermometer klinis digital berbunyi. Data diukur tiga kali sehari setiap pengamatan yaitu pagi hari pukul $06.00-07.00$ siang hari pukul 12.00- 13.00 dan sore hari pukul 17.0018.00 WIB.

\section{Profil darah dan hormon kortisol}

Pengamatan diferensial leukosit dilakukan dengan pengambilan darah secara langsung di lokasi penelitian. Spesimen darah diambil dari vena jugularis dengan menggunakan blood Kit sampling. Selanjutkan dengan pembuatan sediaan apus darah yang diteteskan pada ujung gelas objek kemudian diulas dengan menggunakan gelas objek lain. Setelah kering dilanjutkan dengan fiksasi selama lima menit dalam methanol. Setelah itu, gelas objek kemudian direndam di dalam zat warna giemsa selama 30 menit dan dicuci dengan air mengalir secara perlahan untuk menghilangkan sisa zat warna yang tidak ikut mewarnai sediaan kemudian dikeringkan. Sediaan apus 
darah yang telah diberi pewarnaan kemudian diamati di bawah mikroskop dengan perbesaran objektif 100x untuk menghitung jumlah diferensiasi leukosit hingga jumlah total yang teramati mencapai jumlah 100. Setelah dilakukan persentase diferensiasi leukosit, nilai absolut dari masingmasing jenis leukosit ditentukan dengan cara mengalikan persentase tersebut dengan jumlah total leukosit (Eggen et al. 2001). Penghitungan Indeks Stres dilakukan dengan menggunakan perbandingan neutrofil dengan limfosit $(\mathrm{N}$ $\left.\mathrm{L}^{-1}\right)$ (Kannan et al. 2000).

Pengamatan kadar hormon kortisol diawali denga pengambilan sampel darah melalui vena jugularis dengan menggunakan satu set blood Kit sampling yang terdiri dari: cooler boks, double needle dengan vacuum tube EDTA (Ethylene Diamaine Tetraacetic Acid) needle holder setelah itu serum diperoleh melalui proses centrifuge Alfinus (2012). Analisa hormon kortisol ini mengunakan DRG Cortisol Enzyme Immunoassay Kit (Cortisol ELISA, EIA1887, Germany).

\section{Konsumsi Pakan (kg)}

Rasio pemberian konsentrat baik konsentrat komersil (KK) dan konsentrat hijau (KH Indigofera zollingeriana) pada domba masing masing perlakuan diberi $300 \mathrm{~g} / \mathrm{ekor} / \mathrm{hari}$. Konsentrat KK dan $\mathrm{KH}$ diberikan setiap pagi hari sebelum domba pada sistem pemeliharaan secara semi intensif dilepas ke padang pengembalaan, rumput (Brachiaria humidicola) dan air minum disediakan secara ad libitum di dalam kandang. Kandungan nutrien legum Indigofera zollingeriana perlakuan yang telah dijadikan konsentrat hijau yang diberikan saat perlakuan hasil laboratorium bahwa kandungan nutrien Indigofera zollingeriana memilki BK $81,82 \%$, PK 22,12\% dan SK 16,12\%. Kandungan nutrien pada konsentrat komersil yaitu BK 52,44\%, PK $16,50 \%$, dan SK 18,82\%.

\section{Analisis Data}

Penelitian ini menggunakan rancangan acak lengkap pola faktorial 2 × 2 dengan 6 ulangan. Faktor pertama merupakan 2 taraf perlakuan sistem pemeliharaan, yaitu sistem intensif dan semi intensif, sementara faktor kedua adalah 2 taraf pemberian konsentrat, yaitu konsentrat hijau (Indigofera zollingeriana) dan konsentrat komersial. Pengukuran parameter setiap unit percobaan (domba) dilakukan secara berulang sehingga analisa data menggunakan analisis varian dengan pengukuran berulang (repeated measures analysis of variance) dengan model matematis sebagai berikut :

$\mathrm{Y}_{\mathrm{ijkl}}=\mu+\alpha_{\mathrm{i}}+\beta_{\mathrm{j}}+\alpha \beta_{\mathrm{ij}}+\delta_{\mathrm{ijl} 1}+\mathrm{t}_{\mathrm{k}}+\alpha * \mathrm{t}_{\mathrm{ik}}+\beta^{*} \mathrm{t}_{\mathrm{jk}}+\alpha \beta^{*} \mathrm{t}_{\mathrm{ijk}}+\varepsilon_{\mathrm{ijk} \mathrm{l}}$

Keterangan :

$\mathrm{Y}_{\mathrm{ijk} \mathrm{l}}$ : Pengamatan pada sistem pemeliharaan ke-i, jenis konsentrat ke-j, waktu pengukuran ke-k dan ulangan ke-1

$\mu \quad$ : Rataan umum

$\alpha_{i} \quad$ :Pengaruh sistem pemeliharaan ke-i

$\beta_{\mathrm{j}} \quad$ : Pengaruh pemberian konsentrat ke-j

$\alpha \beta_{\mathrm{ij}}$ : Pengaruh interaksi antara sistem pemeliharaan ke-i dan pemberian konsentrat ke-j

$\delta_{\mathrm{ijl}}$ : Pengaruh acak pada sistem pemeliharaan ke-i, pemberian konsentrat ke-j dan ulangan e-l

$\mathrm{t}_{\mathrm{k}} \quad$ : Pengaruh waktu pengukuran ke-k

$\alpha^{*} t_{i k}$ : Pengaruh interaksi antara sistem pemeliharaan ke-i dengan waktu pengukuran ke-k

$\beta^{*} \mathrm{t}_{\mathrm{jk}}$ : Pengaruh interaksi antara pemberian konsentrat ke-i dengan waktu pengukuran ke-k

$\alpha \beta^{*} \mathrm{t}_{\mathrm{ijk}}$ : Pengaruh interaksi antara sistem pemeliharaan kei, pemberian konsentrat ke-j dan waktu pengukuran ke-k

$\varepsilon_{\mathrm{ijkl}}$ : Pengaruh acak pada sistem pemeliharaan ke-i, pemberian konsentrat ke-j, waktu pengukuran ke-k dan ulangan ke-1

Perbedaan rataan antar perlakuan yang terjadi selanjutnya dilakukan uji nilai tengah kuadrat terkecil (least squares means) menurut Kaps dan Lamberson (2004).

Diferensial leukosit di analisis menggunakan rancangan acak lengkap (RAL) faktorial dengan model matematis sebagai berikut:

$$
\mathrm{Yijk}=\mu+\alpha \mathrm{i}+\beta \mathrm{j}+\alpha \beta \mathrm{ij}+\varepsilon \mathrm{ijk}
$$

Keterangan:

Yijk : Pengamatan pada pemberian jenis konsentrat ke-i, pola pemeliharan ke-j, dan ulangan ke-k

$\mu \quad$ : Rataan umum

$\alpha \mathrm{i} \quad$ : Pengaruh pemberian jenis konsentrat ke-i

$\beta \mathrm{j} \quad$ : Pengaruh pola pemeliharan ke-j

$(\alpha \beta)$ ij : Pengaruh interkasi antara pemberian jenis konsentrat ke-i dan pola pemeliharan ke-j

عijk : Pengaruh acak pemberian jenis konsentrat ke-i, pola pemeliharan ke-j dan ulangan ke-k

\section{HASIL DAN PEMBAHASAN}

\section{Suhu dan kelembapan di lokasi penelitian}

Kisaran suhu dan kelembapan di dalam kandang adalah $20,27-34,83^{\circ} \mathrm{C}$ dan $47,47-74,43 \%$, sedangkan suhu di luar kandang adalah $20,90-38,14^{\circ} \mathrm{C}$ dan kelembapan berkisar 44,38-74,51\%. Pengaruh suhu dan kelembapan sangat penting dalam sistem produksi ternak. Keduanya merupakan salah satu faktor lingkugan yang dapat mempengaruhi secara langsung terhadap performa ternak dan secara tidak langsung dapat mempengaruhi produktifitas domba. Kisaran suhu pada pagi hari di dalam kandang dan luar kandang masih cukup nyaman, karena suhu terssebut masih dalam kondisi normal yang tidak menyebabkan cekaman. Saat siang hari kisaran suhu di luar kandang meningkat mencapai $44,38{ }^{\circ} \mathrm{C}$, suhu ini dapat memberikan cekaman panas karena berada pada suhu kritis maksimum. Yousef (1985) menytakan bahwa daerah Thermoneutral Zone (TNZ) untuk domba berkisar antara $22-31{ }^{\circ} \mathrm{C}$. Peningkatan suhu yang mencapai $44{ }^{\circ} \mathrm{C}$ atau lebih akan mengakibatkan ternak tidak lagi mampu mempertahankan keseimbangan panas pada tubuhya dan mengganggu pertumbuhan serta keadaan reproduksinya. Cekaman panas terjadi pada siang hari dimana panas tubuh ternak meningkat akibat dari suhu lingkungan yang meningkat. Sudarman dan Ito (2000) menyatakan bahwa keadaan suhu lingkungan $30{ }^{\circ} \mathrm{C}$, ternak mempunyai beban panas yang lebih tinggi bila dibandingkan 
dengan ternak yang berada pada suhu lingkungan $20{ }^{\circ} \mathrm{C}$.

Kelembapan udara juga berperan penting dalam mempengaruhi tubuh ternak. Saat suhu lingkungan meningkat, ternak dapat melakukan evaporasi untuk mengurangi cekaman panas terhadap tubuhnya. Kelembapan udara selama pengamatan pada pagi hari 74,51\%. Kelembapan pada penelitian ini masih dalam kondisi normal sesuai Yousef (1985) yang menyatakan bahwa kelembapan untuk lingkungan nyaman pada domba dibawah 75\%. Kelembapan udara yang tinggi dapat mempersulit ternak domba dalam melakukan evaporasi. Saat siang hari kelembapan mencapai nilai yang cukup rendah $44,38 \%$ sehingga ketika tubuh ternak domba mengalami cekaman panas, ternak domba dapat melakukan evaporasi yang menjadi salah satu cara dalam mengurangi cekaman panas. Data suhu dan kelembapan lingkungan dapat dilihat pada Tabel 1 .

\section{Respon Fisiologi Domba}

Respon fisiologi domba merupakan salah satu indikator ternak domba bebas dari rasa tidak nyaman. Rasa tidak nyaman dapat disebabkan oleh lingkungan maupun cara penanganan peternak itu sendiri. Rakhman (2008) mengatakan bahwa faktor-faktor yang mempengaruhi kondisi fisiologis ternak adalah suhu, kelembapan, konsumsi pakan, umur, aktifitas otot, kebuntingan dan stres. Data kondisi respon fisiologi domba selama penelitian dapat dilihat pada Tabel 2.

Hasil penelitian ini menunjukkan bahwa ada interaksi antara sistem pemeliharaan berpengaruh nyata $(\mathrm{P}<0,05)$ Denyut jantung pada penelitian ini secara keseluruhan berada dalam kondisi normal, sesuai dengan pendapat Smith (1998) melaporkan bahwa denyut jantung normal pada domba berkisar 70 - 135 kali menit ${ }^{-1}$. Perbedaan interaksi ini diduga disebabkan domba yang dipelihara secara semi intensif pada siang hari dilepas keluar kandang untuk merumput sehingga konsumsi pakannya lebih tinggi. Wuryatno et al. (2010) menyatakan bahwa kenaikan denyut jantung dapat dipengaruhi oleh peningkatan konsumsi pakan, konsumsi pakan yang meningkat menyebabkan metabolisme tubuh meningkat dan meningkatkan denyut jantung.

Frekuensi denyut jantung yang diperoleh dari hasil penelitian ini lebih rendah apabila dibandingkan dengan hasil Septiadi et al. (2015) yakni berkisar antara 76,68 $\pm 4,13$ kali menit ${ }^{-1}$ sampai $101,39 \pm 6,43$ kali menit $^{-1}$. Kecepatan denyut jantung dikendalikan oleh syaraf, antara lain rangsangan kimiawi seperti hormon dan perubahan kadar $\mathrm{O}_{2}$ dan $\mathrm{CO}_{2}$ maupun dari rangsangan panas luar. Mekanisme peningkatan denyut jantung terjadi ketika terjadi peningkatan suhu darah yang secara langsung mempengaruhi denyut jantung dan juga karena adanya pengaruh penurunan tekanan darah yang berasal dari vasolidatasi peripheral (Nikkah et al. 2008). Produksi panas yang tinggi cenderung meningkatkan denyut jantung yang merupakan mekanisme untuk menjaga tekanan darah stabil akibat dilatasi pembuluh darah (Isnaeni 2006).

Suhu rektal pada penelitian ini masih berada dalam kisaran normal, Marai et al. (2007) melaporkan bahwa kisaran suhu rektal normal pada domba yaitu antara 38,8$39,9^{\circ} \mathrm{C}$, namun dalam pengamatan ini suhu raktal pada sistem semi intensif sedikit lebih tinggi yakni $40,10^{\circ} \mathrm{C}$, perbedaan dari suhu rektal ini diduga dipengaruhi oleh suhu lingkungan, jenis konsentrat dan ruang gerak domba. Exercise dan makan dapat meningkatkan suhu rektal akibat peningkatan metabolisme. Suhu rektal merupakan salah satu indikator yang baik untuk suhu panas tubuh, selain itu suhu rektal merupakan peubah yang dapat menunjukkan efek dari cekaman panas domba.

Hasil penelitian ini menunjukkan bahwa terdapat interaksi antara sistem pemeliharaan dan jenis konsentrat pemeliharaan domba secara semi intensif dengan pemberian KH (Indigofera zolligeriana) pada siang hari memperlihatkan suhu rektal lebih tinggi. Hal ini disebabkan komsumsi konsentrat pada pemeliharaan semi intensif lebih tinggi, hasil ini sesuai dengan pendapat Wuryatno et al. (2010) bahwa tingginya nutrisi yang dikonsumsi akan meningkatkan proses metabolisme tubuh menyebabkan suhu tubuh akan lebih tinggi, sehingga ternak akan mempercepat frekuensi respirasi. Hasil analisis terhadap masing masing perlakuan tidak berbeda, respirasi domba pada penelitian ini berada dalam kisaran normal. Salah satu indikasi terhadap stres panas berada pada kisaran respirasi yang dihasilkan domba, respirasi dapat digunakan sebagai indikator stres karena berhubungan dengan pengeluaran gas $\mathrm{CO}_{2}$ pada jaringan tubuh dan masuknya $\mathrm{O}_{2}$ yang digunakan sebagai pembakaran konsentrat dalam tubuh yang akan menghasilkan panas (Marai et al. 2007).

Faktor waktu (pagi, siang dan sore) pengukuran sangat berpengaruh nyata $(\mathrm{P}<0,05)$ terhadap laju respirasi domba. Rataan repirasi terendah terjadi pada pagi hari, tertinggi pada siang hari sedangkan sore hari walaupun lebih rendah dari siang hari namun lebih tinggi dari pagi hari. Dengan demikian dapat dikatakan bahwa suhu lingkungan berpengaruh terhadap peningkatan frekuensi

Tabel 1. Rataan suhu dan kelembapan lingkungan pada sistem pemeliharaan dan pemberian pakan yang berbeda

\begin{tabular}{lcccc}
\hline Peubah & Posisi & \multicolumn{3}{c}{ waktu pengamatan } \\
\cline { 3 - 5 } & & Pagi & Siang & Sore \\
\hline Suhu $\left({ }^{\circ} \mathrm{C}\right)$ & DL & $20,72 \pm 1,81$ & $34,83 \pm 2,70 \mathrm{~b}$ & $28,06 \pm 3,03$ \\
& LK & $20,93 \pm 1,64$ & $37,93 \pm 2,92 \mathrm{a}$ & $28,23 \pm 3,62$ \\
Kelembapan $(\%)$ & DL & $74,43 \pm 2,19$ & $47,47 \pm 10,32 \mathrm{a}$ & $67,70 \pm 5,22$ \\
& LK & $74,51 \pm 4,34$ & $44,38 \pm 8,13 \mathrm{~b}$ & $68,06 \pm 6,25$ \\
\hline
\end{tabular}

Huruf pada kolom yang sama menunjukkan perbedaan yang nyata $(\mathrm{P}<0,05)$, uji selang berganda: $\mathrm{DL}=$ dalam kandang $\mathrm{LK}=$ luar kandang 
Gonzaga do Santos et al.

Jurnal Ilmu Produksi dan Teknologi Hasil Peternakan 7 (1): 1-9

Tabel 2. Rataan dan standar error respon fisiologi pada domba lokal dengan sistem pemeliharaan dan pemberian jenis konsentrat berbeda

\begin{tabular}{|c|c|c|c|c|c|c|}
\hline \multirow[t]{2}{*}{ Peubah } & \multirow[t]{2}{*}{ SP } & \multirow[t]{2}{*}{$\mathrm{JK}$} & \multicolumn{3}{|c|}{ Waktu } & \multirow[t]{2}{*}{ Rataan } \\
\hline & & & Pagi & Siang & Sore & \\
\hline \multirow{6}{*}{$\begin{array}{l}\text { DJ (kali menit-1) } \\
70-135^{*}\end{array}$} & \multirow[t]{2}{*}{ Intensif } & $\mathrm{KH}$ & $71,78 \pm 1,17$ & $76,61 \pm 1,08$ & $71,11 \pm 1,03$ & $73,17 \pm 3,86$ \\
\hline & & KK & $71,22 \pm 1,16$ & $75,11 \pm 1,08$ & $73,39 \pm 1,03$ & $73,24 \pm 2,61$ \\
\hline & Rataan & & $71,50 \pm 3,05$ & $75,86 \pm 2,44 b$ & $72,25 \pm 2,53$ & \\
\hline & \multirow[t]{2}{*}{ Semi Intensif } & $\mathrm{KH}$ & $71,28 \pm 1,16$ & $78,78 \pm 1,08$ & $71,88 \pm 1,03$ & $73,98 \pm 4,03$ \\
\hline & & KK & $72,07 \pm 1,27$ & $78,94 \pm 1,18$ & $72,27 \pm 1,13$ & $74,42 \pm 4,46$ \\
\hline & Rataan & & $71,67 \pm 2,33$ & $78,85 \pm 2,73 a$ & $72,06 \pm 2,60$ & \\
\hline \multirow[t]{6}{*}{$\mathrm{SR}\left({ }^{\circ} \mathrm{C}\right) 38,8-39,9^{* *}$} & \multirow[t]{2}{*}{ Intensif } & $\mathrm{KH}$ & $38,73 \pm 0,13$ & $39,44 \pm 0,10$ & $39,00 \pm 0,88$ & $39,06 \pm 0,45$ \\
\hline & & KK & $38,93 \pm 0,13$ & $39,54 \pm 0,10$ & $39,01 \pm 0,88$ & $39,16 \pm 0,54$ \\
\hline & Rataan & & $38,83 \pm 0,37 \mathrm{a}$ & $39,49 \pm 0,26 b$ & $39,00 \pm 0,55$ & \\
\hline & \multirow[t]{2}{*}{ Semi Intensif } & $\mathrm{KH}$ & $38,33 \pm 0,13$ & $39,98 \pm 0,10$ & $37,57 \pm 0,88$ & $38,62 \pm 2,46$ \\
\hline & & KK & $38,63 \pm 0,14$ & $40,10 \pm 0,11$ & $39,18 \pm 0,97$ & $39,30 \pm 0,69$ \\
\hline & Rataan & & $38,47 \pm 0,25 \mathrm{~b}$ & $40,03 \pm 0,23 \mathrm{a}$ & $38,30 \pm 3,04$ & \\
\hline \multirow{6}{*}{$\begin{array}{l}\text { Respirasi (kali menit-1) } \\
26-54 *\end{array}$} & \multirow[t]{2}{*}{ Intensif } & $\mathrm{KH}$ & $28,39 \pm 1,16$ & $33,34 \pm 0,93$ & $29,17 \pm 0,91$ & $30,30 \pm 3,56$ \\
\hline & & KK & $28,95 \pm 1,16$ & $31,28 \pm 0,93$ & $27,00 \pm 0,91$ & $29,07 \pm 3,25$ \\
\hline & Rataan & & $28,67 \pm 3,64$ & $32,31 \pm 2,70 \mathrm{~b}$ & $28,08 \pm 2,27 b$ & \\
\hline & \multirow[t]{2}{*}{ Semi Intensif } & $\mathrm{KH}$ & $26,17 \pm 1,16$ & $39,28 \pm 0,93$ & $31,72 \pm 0,91$ & $32,30 \pm 5,83$ \\
\hline & & KK & $25,80 \pm 1,27$ & $37,53 \pm 1,02$ & $29,00 \pm 0,99$ & $30,78 \pm 5,34$ \\
\hline & Rataan & & $26,00 \pm 0,92$ & $38,48 \pm 1,96 a$ & $30,48 \pm 2,66 a$ & \\
\hline
\end{tabular}

Huruf pada kolom yang sama menunjukkan perbedaan yang nyata $(\mathrm{P}<0.05)$ SP: sistem pemeliharaan JK: jenis konsentrat KH: konsentrat hijau KK: konsentrat komersil DJ: denyut jantung SR: suhu rektal. Nilai normal menurut *DJ Smith (1998) dan **SR Marai et al. (2007)

Tabel 3. Rataan dan standar error diferensial leukosit (\%) pada domba lokal dengan sistem pemeliharaan dan pemberian jenis konsentrat berbeda

\begin{tabular}{llccc}
\hline SP & Peubah (\%) & \multicolumn{2}{c}{ Jenis Konsentrat } & Rataan \\
\cline { 3 - 4 } & & $\mathrm{KH}$ & $\mathrm{KK}$ & $39,70 \pm 2,72$ \\
\hline Intensif & Limfosit & $41,15 \pm 2,93$ & $38,26 \pm 2,93$ & $50,18 \pm 2,15$ \\
& Neutrofil & $48,98 \pm 3,05$ & $51,39 \pm 3,05$ & $2,59 \pm 0,28$ \\
& Monosit & $2,72 \pm 0,41$ & $2,45 \pm 0,41$ & $6,04 \pm 0,67$ \\
& Eosinofil & $6,61 \pm 0,95$ & $5,47 \pm 0,95$ & $1,32 \pm 0,11$ \\
\hline Semi intensif & N/R & $1,27 \pm 0,16$ & $1,37 \pm 0,16$ & $44,72 \pm 2,17$ \\
& Limfosit & $42,54 \pm 2,93$ & $46,90 \pm 3,21$ & $44,98 \pm 2,56$ \\
& Neutrofil & $46,01 \pm 3,05$ & $43,95 \pm 3,34$ & $2,58 \pm 0,30$ \\
& Monosit & $2,26 \pm 0,41$ & $2,92 \pm 0,45$ & $7,64 \pm 0,71$ \\
& Eosinofil & $7,85 \pm 0,95$ & $7,43 \pm 1,05$ & $1,06 \pm 0,12$ \\
\hline
\end{tabular}

SP: sistem pemeliharaan KH: konsentrat hijau KK: konsentrat komersil

respirasi domba. Pengaruh suhu dan kelembapan yang tinggi dapat menyebabkan penggunaan energi untuk pertumbuhan domba kurang efisien, karena sebagian energi digunakan untuk aktivitas fisiologi terutama pada respirasi. Dari segi sistem pemeliharaan, menunjukkan bahwa rataan respirasi domba dengan pemeliharaan semi intensif lebih tinggi 38,48 $\pm 1,96$ dibanding dengan intensif $32,31 \pm 2.70$, hal ini dapat dikatakan bahwa suhu lingkugan berpengaruh terhadap respirasi domba. Jenis konsentrat yang dikonsumsi tidak berpengaruh nyata $(\mathrm{P}<0,05)$ pada sistem pemeliharaan. Laju respirasi masih dalam tahap normal apabila dilihat kisaran normal respirasi domba lokal. Wuryanto et al. (2010) menyatakan bahwa tingginya nutrisi yang dikonsumsi akan menigkatkan proses metabolisme tubuh sehingga suhu tubuh akan lebih tinggi, sehingga ternak akan lebih mempercepat frekuensi respirasi.

\section{Diferensial Leukosit}

Jumlah total leukosit dan rasio Neutrofil/Limfosit $(\mathrm{N} / \mathrm{L})$ pada sistem pemeliharaan dan pemberian jenis konsentrat berbeda ditampilkan pada Tabel 3. Evaluasi kesejahteraan domba dapat dilakukan melalui indikator bebas dari rasa sakit, cedera dan penyakit. Indikator ini 
dapat dilihat dari pencegahan penyakit dan pengontrolan kesehatan domba sebab kesehatan ternak merupakan salah satu faktor yang mempengaruhi produktivitas ternak, dan salah satu hal yang berpengaruh pada kesehatan tersebut adalah leukosit (Saputro 2016). Kelly (1984), leukosit terdiri dari dua tipe yaitu polimorfonuklear leukosit (granulosit) dan mononuklear leukosit (agranulosit). Leukosit granule terbagi menjadi tiga yaitu neutrofil, basofil dan eosinofil. Ketiga jenis tersebut memiliki peran tersendiri sebagai imunitas tubuh. Agranulosit terdiri dari limfosit dan monosit.

Hasil analisis statistik menunjukkan bahwa tidak ada pengaruh interaksi antara sistem pemeliharaan dengan jenis konsentrat terhadap limfosit, monosit, neutrofil, basofil dan eosinofil demikian pula dengan masing masing perlakuan tidak berpengaruh nyata terhadap limfosit, monosit, neutrofil, basofil dan eosinofil. Hal ini disebabkan kondisi ternak pada pemelihraan domba berada dalam kondisi normal dan sehat, menurut Guyton dan Hall (1997) menyatakan bahwa konsentrasi leukosit dipengaruhi oleh beberapa faktor meliputi umur, jenis kelamin, penyakit dan hormon maupun keadaan lingkungan, aktivitas ternak, stres dan pakan yang diberikan. Nilai dari limfosit, monosit, neutrofil, basofil dan eosinofil pada penelitian ini juga berada dalam kisaran normal.

\section{Rasio Neutrofil/Limfosit (Rasio N/L)}

Bebas dari rasa sakit, cedera dan penyakit dapat diukur dengan kemampuan mencegah kemungkinan timbulnya penyakit melalui pemeriksaan leukosit darah. Salah satu respon tubuh menghadapi stressor diketahui dengan adanya peningkatan hormon glukokortikoid, yang juga berdampak pada fluktuasi jumlah neutrofil dan limfosit dalam darah Wulansari et al. (2015). Perubahan rasio neutrofil/limfosit (N/L) merupakan indikator untuk menilai respon individu terhadap perubahan lingkungan Maheshwari et al. (2013).

Nilai N/L pada penelitian ini tidak berbeda secara statistik baik pengaruh perlakuan maupun interaksi. Hal ini disebabkan oleh suhu pemeliharaan pada penelitian ini relatif sama sehingga tidak terjadi stres panas yang menyebabkan nilai N/L cukup tinggi. Rasio N/L merupakan indikator adanya stres. Altan et al. (2000) menyatakan bahwa stress menyebabkan rasio N/L meningkat hal ini disebabkan hormon yang meningkatkan stres disekresikan oleh kelenjar adrenal akan meningkatkan rasio N/L Gudev et al. (2011).

Penelitian ini menunjukkan domba dengan pemeliharaan semi intensif maupun intensif dengan pemberian konsentrat yang berbeda memiliki rasio N/L yang normal sesuai dengan pendapat Kannan et al. (2000) bahwa nilai normal rasio N/L pada domba yaitu sebesar $1,5 \%$. Hal ini mengindikasikan domba dengan sistem pemeliharaan dan jenis konsentrat berbeda tahan terhadap cekaman stres, termasuk lebih toleran terhadap suhu panas yang menjadi kendala di peternakan negara tropis.

Stres yang berasal dari lingkungan menyebabkan tubuh mengaktifkan hypothalamicpituitary-adrenal cortical system yang menyebabkan hipotalamus menghasilkan corticotrophin realising factor (CRF). CRF merangsang pituitari untuk melepaskan hormon ACTH (adrinoccorticatropin hormone) sehingga jaringan korteks adrenal menghasilkan hormon kortikosteroid. Hormone kortikosteroid menyebabkan penurunan kadar limfosit. Penurunan limfosit ini menyebabkan sistem kekebalan tubuh menurun. Terganggunya fungsi kekebalan tubuh tersebut ditandai dengan peningkatan rasio N/L dalam darah Davis et al. (2008). Menurut Robbins dan Czekala (1997) bahwa rasio N/L dapat dipengaruhi oleh lingkungan, pakan, transportasi dan perbedaan umur dapat mempengaruhi tingkat stres. Nilai rasio antara neutrofil dan limfosit domba lokal pada sistem pemeliharaan dan jenis konsentrat yang berbeda terbukti tidak memberikan pengaruh cekaman

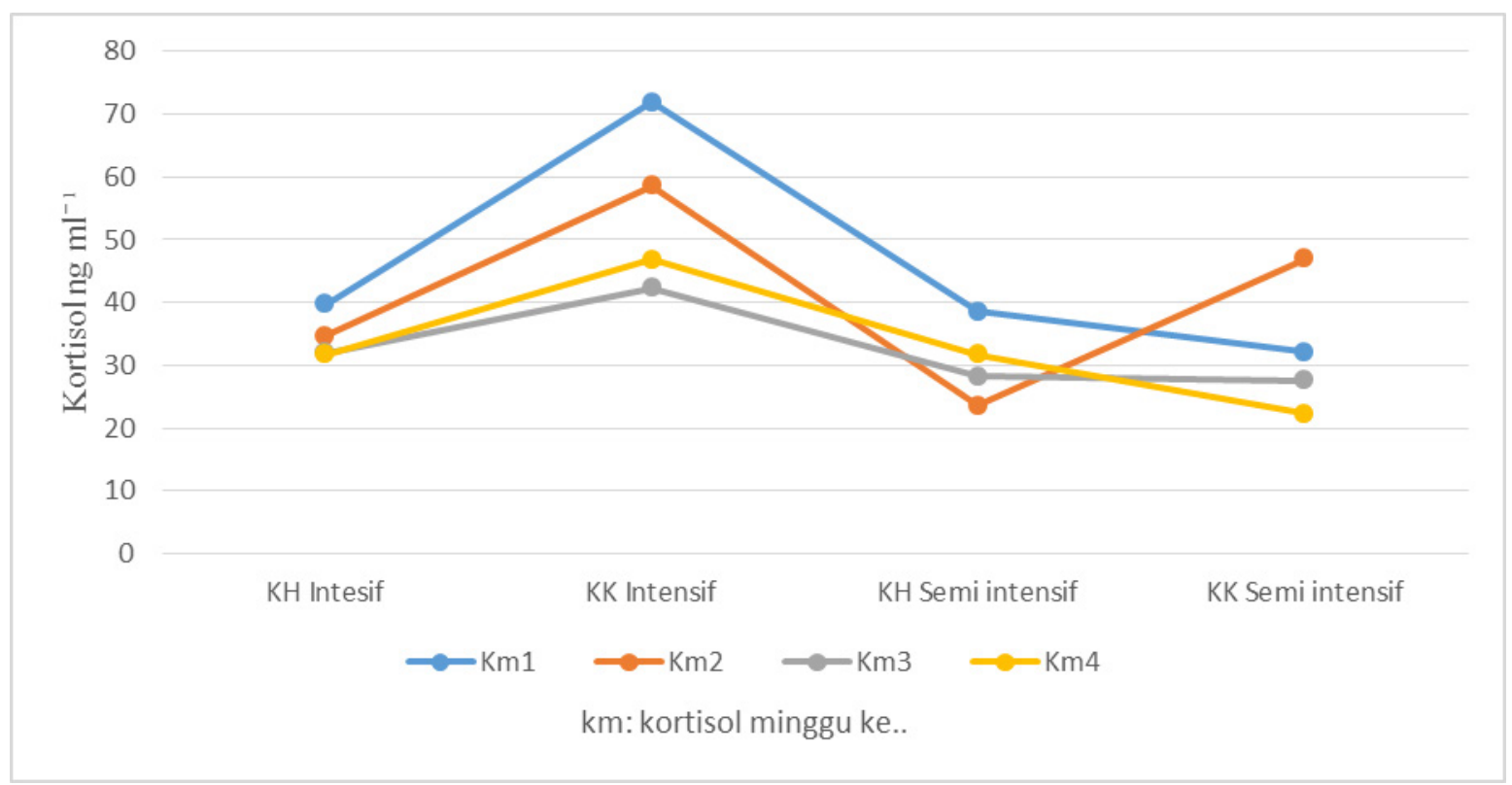

Gambar 1. Rataan dan standar error kadar hormon kortisol (ng $\mathrm{ml}^{-1}$ ) pada domba lokal dengan sistem pemeliharaan dan pemberian jenis konsentrat berbeda 
panas yang di terima domba lokal.

\section{Neutrofil}

Neutrofil berfungsi memfagositosis, membunuh organisme serta membatasi penyebaran mikrooganisme, melawan infeksi dengan cara migrasi menuju jaringan yang terinfeksi oleh bakteri, menembus dinding kapiler dengan cara diapedesis dan memfagosit bakteri tersebut. Neutrofil menuju jaringan yang terluka ataupun, kemudian melepaskan zat-zat kemotoksik. Sel-sel yang mengalami luka atau kerusakan melepaskan histamin yang membantu mengawali proses peradangan Frandson (1992). Neutrofil merupakan sel darah putih yang memilki masa hidup yang pendek dalam sistem peredaran darah. Peningkatan jumlah neutrofil dapat mengakibatkan infeksi bakteri akut, inflamasi dan maglinansi. Neutrofil juga dapat membantu sistem daya tahan tubuh.

Hasil anaslisis statistik menunjukkan gambaran diferensial leukosit pada sistem pemeliharaan tidak berbeda nyata dengan jenis konsentrat $(\mathrm{P}<0,05)$, hal ini mengindikasikan bahwa domba dengan perbedaan sistem pemeliharaan dan jenis konsentrat tidak membawa perubahan yang berbeda berdasarkan gambaran diferensial leukositnya, hal ini dapat diduga bahwa perlakuan yang diberikan bermanfaat yang benar bagi domba. Nilai neutrofil berkisar 43,95-51,38\%, nilai neutrofil pada perlakuan masih berada dalam kisaran normal, yaitu berkisar antara 10-50\% $\mu$ Jain (1993).

\section{Basofil dan Eosinofil}

Basofil dan eosinofil mempunyai fungsi yang sama yaitu sebagai sel darah yang merespon terhadap reaksi alergi dan mencegah terjadinya penggumpalan darah karena mengandung histamin (Lawhead dan Baker 2005). Adapun basofil pada penelitian ini tidak ditemukan, hasil analisis statistik menunjukkan bahwa perbedaan sistem pemeliharaan dan jenis konsentrat pada domba lokal tidak berpengaruh nyata $(\mathrm{P}<0,05)$ terhadap presentase eosinofil. Presentase eosinofil dalam penelitian ini berkisar antara 5,47-7,85\%. Presentase eosinofil pada domba lokal lebih rendah dengan hasil penelitian Atik (2015) yaitu dengan pemberian limbah tauge pada domba garut di Jonggol memiliki presentase eosinofil sebesar $14,60 \%$, hal ini dapat diduga bahwa sistem pemeliharaan dan sifat resistensi domba lokal terhadap suatu lingkungan. Eosinofil merupakan sel fagosit yang motil dan memiliki kemampuan memfagosit dan membunuh bakteri, walaupun kemampuannya lebih rendah dibandingkan dengan neutrofil (Dellman dan Eurell 1998).

Eosinofil termasuk leukosit jenis granulosit yang berukuran hampir sama dengan neutrofil. Eosinofil berfungsi sebagai indikasi parasitosis, alergi dan kondisi lainnya. Presentase eosinofil dalam penelitian ini berada dalam kisaran normal 5,47-7,85\%. Menurut Meyer dan Harvey (2004) bahwa presentase eosinofil dalam sirkulasi darah domba yang sehat berkisar antara 2-8\% dari jumlah total leukosit. Hal ini diduga karena adanya keseimbangan nutrien yang dicerna sehingga mencukupi kebutuhan domba dan dapat mempengaruhi leukosit. Pemberian kandungan nutrien yang dibutuhkan oleh domba untuk pertumbuhan dan sistem imun tubuh menyebabkan sistem imunitas tubuh meningkat. Meningkatnya sistem imun dapat dilihat dari gambaran darah domba karena darah mempunyai fungsi penting dalam pengaturan fisiologis tubuh Saputro et al. (2016).

\section{Limfosit}

Limfosit adalah leukosit agranulosit dan merupakan leukosit terbanyak dalam darah domba, mempunyai bentuk dan ukuran yang bervariasi. Perbedaan jumlah limfosit pada perlakuan dapat didefinisikan bahwa perbedaan perlakuan dan konsumsi konsentrat dapat menimbulkan meningkatnya jumlah limfosit, hal ini tejadi karena limfosit mampu menerobos jaringan atau organ lunak yang berguna untuk penyediaan zat kebal bagi pertahanan tubuh, fungsi limfosit untuk membunuh dan memakan bakteri yang masuk ke dalam jaringan tubuh, stresor yang berlebih dapat menyebabkan penurunan jumlah limfosit dalam darah. Hasil analisis statistik bahwa perbedaan perlakuan tidak berpengaruh nyata $(\mathrm{P}<0,05)$ terhadap presentase limfosit, secara umum presentase limfosit pada perlakuan pemeliharaan dan jenis konsentrat pada penelitian ini berada dibawah kisaran normal 38,26-46,90\%. Menurut Scham et al. (1986) presentase limfosit normal pada domba berkisar 40-70\%. Penurunan jumlah limfosit dalam sirkulasi darah dapat terjadi karena pengaruh glukortikoid (endogen/eksogen), pengunaan obat obatan imunosupresif, dan radiasi yang menyebabkan kerusakan sel darah putih Meyer dan Harvey (2004).

Monosit

Monosit dalam jaringan disebut makrofag, markofag berperan penting bagi tubuh untuk melawan infeksi mikroba. Hal ini dikarenakan monosit dalam keadaan normal merupakan sumber pembentukan makrofag tetap pada mononuklear phagocytes system (MPS) serta tidak langsung monosit memberi tanda pada MPS untuk menjalankan fungsinya Jain (1993). Hasil analisis statistik menunjukkan bahwa perbedaan sistem pemeliharaan dan jenis konsentrat tidak berpengaruh nyata $(\mathrm{P}<0,05)$ terhadap presentase monosit. Presentase monosit pada domba lokal berkisar antara 2,26-2,91\%. Presentase monosit domba lokal dalam penelitian ini berada dalam kisaran normal hal ini sesuai dengan Scham et al. (1986) bahwa kisaran normal monosit pada domba sehat berkisar antara 0-6\%.

\section{Kadar Kortisol}

Aspek kesejahteraan hewan lain yang penting adalah bebas dari rasa takut dan stres. Stres merupakan suatu kondisi pada ternak sebagai akibat dari satu atau lebih sumber stres (stressor) baik dari dalam tubuh ternak maupun pengaruh dari lingkungan sekitarnya. Adelodun et al. (2012) mengatakan bahwa faktor lingkungan memberikan dampak baik secara langsung maupun tidak langsung terhadap ternak. Domba pada sistem pemeliharaan intensif dengan KK mempunyai kadar kortisol lebih tinggi yakni 54,91 ng/ $\mathrm{ml}$ daripada domba pada sistem pemeliharaan semi intensif dengan konsentrat komersil yakni 32,23 ng/ml.

Berdasarkan grafik kadar kortisol menunjukkan bahwa kadar kortisol mengalami peningkatan pada minggu pertama pada masing-masing pemeliharaan dengan konsumsi KK. Peningkatan kadar kortisol ini disebabkan karena domba penelitian harus beradaptasi dengan perubahan lingkungan, misalnya suhu lingkungan 
dan adanya interaksi dengan domba lain serta perubahan konsumsi konsentrat. Perubahan lingkungan dan pakan menyebabkan domba menjadi stres. Sedangkan pada masing-masing sistem pemeliharaan dengan $\mathrm{KH}$ minggu pertama, kedua, ketiga dan keempat tidak menunjukkan peningkatan kadar kortisol. Menurut Minton et al. (1992) bahwa pada domba yang mengalami stres, kadar kortisol dapat mencapai $70 \mathrm{ng} / \mathrm{ml}$, sedangkan pada kelompok tanpa perlakuan stres kadar kortisol berkisar $20 \mathrm{ng} / \mathrm{ml}$. Dengan pernyataan ini dapat disimpulkan bahwa domba pada sistem pemelihraan dan jenis kosentrat berbeda nilai kadar kortisol masih berada dalam kisaran normal. Kadar awal kortisol darah ini lebih tinggi dari kadar kortisol normal domba luar negeri. Menurut Kannan et al. (2000) kadar normal kortisol adalah $10-15 \mathrm{ng} / \mathrm{ml}$.

Apabila terjadi perubahan fisiologi pada tubuh hewan maka gambaran darah juga ikut mengalami perubahan. Perubahan gambaran darah secara internal disebabkan oleh pertambahan umur, keadaan gizi, latihan, stres, kebuntingan, kesehatan, dan suhu tubuh. Adapun perubahan secara eksternal berupa perubahan suhu lingkungan, infeksi kuman penyakit, fraktura dan lain sebagainya (Satyaningtijas et al. 2010). Ternak memberikan respon terhadap stres dengan menghasilkan hormon kortisol yang menurunkan jumlah limfosit. Chastain dan Ganjam (1986) melaporkan bahwa diduga kadar kortisol yang tinggi dapat menghambat sekresi limfosit dari sumsum tulang dan hewan akan mengalami stres psikologis apabila kadar kortisol dalam darah meningkat. Grandin (2000) menyatakan bahwa peningkatan kadar kortisol merupakan salah satu indikator stres yang sering digunakan dalam penilaian aspek kesejahteraan hewan.

\section{KESIMPULAN}

Pemberian perbedaan jenis konsentrat pada masing masing sistem tidak memberikan pengaruh terhadap kondisi respon fisiologis namun sistem pemeliharaan berpengaruh terhadap respon fisiologis domba. Melalui pemeriksaan kadar hormon kortisol sistem pemeliharaan secara intensif cenderung meningkatkan tingkat stres pada ternak domba.

\section{DAFTAR PUSTAKA}

Adelodun O.F, Sunday O.P, Abdulmojeed O. S, Matthew A.A, Michael O. 2012. Physiological and haemological incides suggest superior heat tolerance of whitecoloured West African Dwarf sheep in the hot humid tropics. J Trop Anim Health Prod. 10(2012): 1-9.

Adhiarta I.G.N, Soetedjo N. 2009. Krisis Adrenal. Bandung. Fakultas Kedokteran Universitas Padjajaran Sub Bagian Endokrinologi dan Metabolisme Bagian Imu Penyakit dalam RS. Hasan Sadikin.

Alfinus. 2012. Laporan apresiasi keterampilan laboratorium medik dan paramedik veteriner sewilayah kerja balai besar vseteriner Maros.

Altan O, Altan A, Cabuk M, Bayraktar H. 2000. Effects of heat stress on some blood parameters in broiler. J Vet Anim Sci. 24: 145-
148.

Atik. 2015. Respon fisiologi, Tingkah Laku dan Hematologi Domba Garut dan dan Jonggol Jantan dengan Pemberian Limbah Tauge pada Sore Hari. (Tesis) Bogor (ID) Institut Pertanian Bogor IPB.

Atrian P.A. dan Shahryar. 2012. Heat stress in dairy cows (review). Reseach in Zoology. 2 (4):31-37

Brinkmann dan Zyclhinsky. 2012. Neutrophil extracellular traps: is immunity the second funcion of chromatin. J. Biology. 198 (5): 773.

BPS Badan Pusat Statistik Peternakan dan Kesehatan Hewan 2017. Populasi ternak ruminansia. [Internet]. [22 September 2017]: http://www.republika.co.id/ berita/ekonomi/makro/17/09/22/owonuc423

Chastain CB, Ganjam VK. 1986. Clinical Endocrinology of Companion Animals. Philadelphia: Lea \& Febiger.

Davis AK, Ma ney DL, Maerz JC. 2008. The use of leukocyte profiles to measure stress in vertebrates: a review for ecologists. Funct Ecol. 22(5):760-772.

Dellman DH, Eurell JA. 1998. Texbooks of Veterinary Histology. Ed ke5. USA (US): A Wolsters Kluwer Company.

Eccleston K.J. 2009. Animal Welfare di Jawa Timur: Model Pendidikan Kesejahteraan Binatang di Jawa Timur. Australian Consortium For In-Country Indonesian Studies Angkatan Ke- 28.

Frandson R.D. 1992. Anatomy and Phisiology. B. Srigandono, K. Preseno, dan Soedarsono, penerjemah Anatomi dan fisiologi ternak Ed. Yogyakarta. Gajah Mada University Press.

Grandin T. 2000. Antemortem handling and welfare. Di dalam: Hui YH, editor. Meat science and application. New York: Marcel Dekker.

Gudev D, Popova-Ralcheva S, Ianchev I, Moneva P. 2011. Effect Of Betaine And Air Ammoniaconcentration On Broiler Performance, Plasma Corticosterone Level, Lymphoid Organ Weights And Some Haematological Indices. Biotech in Animal Husb. 27 (3): 687-70.

Guyton AC dan Hall JE. 1997. Buku Ajar Fisiologi Kedokteran. Irawati Setiawan, Penerjemah. Jakarta (ID): EGC.

Isnaeni W. 2006. Fisiologi Hewan. Kanisius, Jakarta.

Jain NC. 1993. Essential of Veterinery Hematology. Philadelphia: Lea \& Febiger.

Kannan G, Terril T.H, Kouakou B, Gazal O.S, Gelaye S, Amoah E.A Samake S. 2000. Transportation of goats: effects on physiological stress responses and live weight loss. J Animal Sci. 78(2000): 1450-1457.

Kaps M, WR Lamberson. 2004. Biostatistics for Anim Sci. Oxfordshire (GB): CABI Publishing.

Kelly WR. 1984. Veterinary Clinical Diagnosis. London (UK) : Bailliere Tindall.

Linares M.B.R, Bórnez H, Vergara. 2007. Cortisol and catecholamine levels in lambs: Effects of slaughter weight and type of stunning. J Livestock Science 115 (2008) 53-61

Lawhead JM and Baker. 2005. Introduction to Veterinary Science. New York (US): Delmar.

Maheshwari H, Yulnawati A. Esfandiari, Andriyanto 
M.D. Andriani A. Khovifah. 2013. Profile of Cortisol, Triiodothyronine, Thyroxine and Neutrophil/Lymphcyte Ratio as Stress Indicators in Swamp buffaloes 15 Days pst-Transportation. Deparment of Anatomy, Physiology and Pharmacology, Faculty of Veterinary Medicine, Bogor Agriculture University. J. Media Peternakan(2013): 106-112.

Marai I. F. M, A. A. El-Darawany A. Fadiel M. A. M Abdel-Hafez. 2007. Physiological traits as affected by heat stress in sheep. Small Ruminant Research. (Egypt) 71: 1-12.

Merey JD, Harvey WJ. 2004. Veterinary Laboratory Medicine Interpretation and Diagnosis. USA (US): Saunders.

Minton JE, Coppinger TR, Reddy PG, Davis WC, Blecha F. 1992. Repeated restraint and isolation stress alters adrenal and lymphocyte functions and some leukocyte differentiation antigens in lamb. J Anim Sci 70:11261132.

Nieslon K. S. 1995. Animal Physiology. In: Nielson Knut (Ed.). Adaptation and Environment 4th ed. Cambridge (US): Cambridge University Pr.

Nikkhan E. N, Schirman K, Stewart M. 2008. Effect of delivery time on feed intake, milk productin and blood metabolites of dairy cows. J Dairy Sci. 9(2008):42494260.

Nurmi A. 2016. Respons fisiologis domba lokal dengan perbedaan waktu pemberian pakan dan panjang pemotongan bulu. J Fakultas Peternakan Universitas Muhammadiyah Tapanuli Selatan. 58 (1): 60.

Rakhman A. 2008. Studi Pengaruh Unsur Cuaca terhadap Respon Fisiologi dan Produksi Susu Sapi Perah PFH di Desa Cibogo dan Lengansari, Lembang, Bandung Barat. [Skripsi]. Bogor : Fakultas Peternakan Insitut Pertanian Bogor.

Robbins M.M. dan Czekala N.M. 1997. A preliminary investigation of urinary testosterone and cortisol leves in wild male maountain gorrilas. Am J primatol. 43:5164

Rosyidi D. 2006. Beberapa Aspek Biologi Kancil. J IlmuIlmu Hayati (Life Science). 18(1).

Schalm CM, Jain NC, Carrol EJ. 1986. Veterinary Hematology. 4th Ed. Ithaca, New York, ML Scoot and Association.

Saputro B.E, R. Sutrisna, P.E. Santosa, F. Fathul. 2016. Pengaruh Ransum yang Berbeda pada Itik Jantan Terhadap Jumlah Leukosit dan Diferensial Leukosit. Universitas Lamung, Fakultas Pertanian Jurusan Peternakan. J.Peternakan terpadu vol. 4 (3): 176-181.

Satyaningtijas AA, Ramadhoni A, Dewi YSF, Sutisna A. 2010. Efektivitas multivitamin dan meniran (Phyllanthus neruri L.) dalam menurunkan stres pada domba selama transportasi. Departemen Anatomi, Fisiologi dan Farmakologi-Institut Pertanian Bogor. Berita Biologi. 10(3): 393-399.

Septiadi A. N. H, Handarin R. 2015. Kondisi fisiologi domba ekor tipis jantan yang diberi berbagai level ransum fermentasi isi rumen sapi. Fakultas Pertanian Universitas Djuanda Bogor. ISSN 2442- 2541 1(2) .
Sirait J, Syawal M, Simanihuruk K. 2010. Tanaman alfalfa (Medicago sativa.L) Adaptif Dataran Tinggi Iklim Basah sebagai Sumber Pakan: Morfologi, Produksi dan Palatabilitas. Di dalam : Prosiding Seminar Nasional Teknologi Peternakan dan Veteriner. Sumatera Utara (ID): Puslitbang Peternakan. Hal : 519-528.

Smith JB, Mangkoewidjojo S. 1988. Pemeliharaan, Pembiakan dan Penggunaan Hewan Percobaan di daerah Tropis. UI Press, Indonesia.

Sudarman A, Ito T. 2000. Heat production and thermoregulatory response of sheep fed roughage proportion diets and intake level when exposed to a high ambient temperature. Asian-Aus. J. Animal Science 13: 1523-1528.

Yani A, Al-Zahra W, Purwanto BP. 2013. Response of Heart and Respiratory Frequency Bali Cattle Based on Changes in Temperature and Humidity in the Wet Tropical Climates Using Artifical Neural Networks. Jurnal Ilmu Produksi dan Tehnologi Hasil Peternakan. 1(1): 54-62.

Yousef MK. 1985. Stress Physiology in Livestock. Vol.1 Basic Principles. Florida (US): CRC Press Inc.

Wilson PG, Rowe R. 2008. A revision of the Indigofereae (Fabaceae) in Australia. Indigofera species with trifoliolate and alternately pinnate leaves. TELOPEA J Plant Syst. 12:293-307.

Wulansari AY, Hernawan E. 2015. Pengaruh pemberian elektrolit berbasis air kelapa (Cocos nucifera) dan ekstrak rosela (Hibiscus sabdariffa) sebelum transportasi terhadap profil leukosit domba priangan. Fakultas Peternakan Universitas Padjadjaran.

Wuryatno IPR, Darmoatmodjo LMYD, Dartosukarno S, Arifin M, Purnomoadi. 2010. Produktivitas, respon fisiologis dan perubahan komposisi tubuh pada sapi jawa yang diberi pakan dengan tingkat protein berbeda. Seminar Nasional Teknologi Peternakan dan Veteriner 2010 . 